Nagy Imre őrmester:

\title{
A TENGEREK BIZTONSÁGÁRÓL, KÜLÖNÖS TEKINTETTEL A GUINEAI-ÖBÖL TÉRSÉGÉRE
}

DOI: $\underline{10.35926 / \mathrm{HSZ} .2021 .1 .4}$

ÖSSZEFOGLALÓ: A tengeri közlekedés és szállitás biztonsága - különösen Afrika viszonylatában - látszólag távol eshet a magyar közérdeklődéstől, valamint a rend-és honvédelmi szervezetek mindennapos feladataitól. A déli iránnyal is bíró nemzeti kül- és külgazdasági politika, illetve Magyarország NATO- és EU-tagsága miatt is azonban immár szélesebb keretben kell biztonságunkat értékelni. Az interdependencia és a globalizáció korában a földrajzilag távoli térségekben zajló folyamatokat is érdemes figyelemmel kísérni és elemezni, hogy időben adekvát válaszlépések születhessenek, ha szükséges. A Guineai-öböl az elmúlt években a legveszélyesebb területté vált a kalózkodás szempontjából, de a szervezett bünözői tevékenység és kábítószer-csempészet mértéke és társadalmi beágyazottsága is aggasztó - mivel összefüggenek és táplálják a Nigériában és a Száhel övezetben müködö, az itteni államok müködőképességét aláásó szélsőséges szervezetek harcát. A Maliban növekvő szerepet vállaló Magyar Honvédség szempontjából sem mellékes, hogy ezek a csoportok a forrásaiktól elszigetelődjenek, marginalizálódjanak, ezzel pedig a tartós rendezéshez szükséges biztonsági feltételek megteremtődjenek.

KULCSSZAVAK: tengeri terrorizmus, kalózkodás, Niger-delta-felkelés, Afrika Integrált Tengeri Stratégiája 2050, Yaoundéi Egyezmény

\section{BEVEZETÉS}

Az időnkénti tengeri katasztrófák, az elharapózott szomáliai kalózkodás vagy az afrikai menekültek drámai átkelési kísérletei Európa felé a közfigyelmet csak időnként irányítják a vizek felé, melyek pedig meghatározó globális folyamatok és történések színterei - nem mellesleg pedig az emberi élet feltételei biztosításának sine qua nonja. ${ }^{1}$ Stratégiai gazdasági és biztonsági érdekek feszülnek egymásnak mind látványosabban a Dél-kínai-tengeren vagy az arktikus térségben, felértékelve a haditengerészeti és a kétéltű katonai képességeket, ugyanakkor nyugtalanítva a hajózókat. A tengeren zajló (regisztrált, jelentett) büncselekmények és terroresemények a forgalom nagyságához viszonyítva látszólag nem számosak.

A tengeri csempészet pedig - noha kevésbé látványos, de folyamatos tevékenységként a korrupciót élteti, emellett a gyenge államokat aláássa, és nemritkán a szárazföldön müködő terrorista és gerillaszervezetek számára komoly bevételül szolgál. Az illegális túlhalászat vagy a tengerek szándékos szennyezése hulladéklerakással szintén fontos kérdések, hiszen

\footnotetext{
1 Elengedhetetlen feltétel (latin).
} 
ezek a jelenségek nagyban hozzájárultak például Szomália esetében, hogy a megélhetés és védelem nélkül maradt halászok és volt tengerészek rizikót vállalva kalózkodásba fogtak.

A magyarországi híradásokban leginkább a Hormuzi-szoros és az Ádeni-öböl neve bukkan fel, nem lebecsülendő fontosságú azonban Afrika nagy beöblösödése, vagyis a Guineai-öböl, ahol a világ összes kalóztámadásának mintegy ötöde történt 2019-ben. A Nemzetközi Kereskedelmi Kamara Nemzetközi Tengerészeti Irodája (International Chamber of Commerce - International Maritime Bureau - ICC-IMB) 2019. évi jelentése 2 szerint világszerte 162 kalózcselekményt és hajó elleni fegyveres támadást jelentettek: 130 esetben a támadók feljutottak a hajóra, négy hajót eltérítettek, 17-szer sikertelenül kíséreltek meg támadást, 11-szer történt pusztán rálövés - szemben a 2018-as 201 incidenssel. ${ }^{3}$ A hajók döntő többsége ömlesztett árut szállított, illetve tanker volt, és jobbára nem mozogtak, hanem éppen horgonyoztak. A 162 eseményből 71-re Afrika vizein került sor, és míg a szomáliai vizekről már egyetlen esetet sem jelentettek, addig a Guineai-öbölben történt mind a négy hajóeltérítés, raboltak el 121 föt a 134-ből, illetve a hajók elleni 11 rálövésből 10 itt történt.

Néhány esetet érdemes felidézni - a teljesség igénye nélkül - 2019/2020 fordulójáról:

- 2019 augusztusában a kameruni Douala közelében pár órás különbséggel két hajó is támadás áldozatául esett, ekkor 17 foglyot ejtettek;

- november második napján az ömlesztett árut szállító norvég Bonita kilenc filippínó tengerésze esett fogságba Benin partjainál;

- két nappal később pedig a Vizcayai-öböl felé tartó görög Elka Aristotle tankerre fellopakodott rablók a togói Lométól mindössze 10 tengeri mérföldnyire tüzharcban megsebesítették a fegyveres őrt, majd négy túszt ejtettek;

- még november 20-án Egyenlítői-Guineánál került sor újabb incidensre: a szingapúri Pacific Warden ellátóhajó legénységéből hét fö került fogságba egy hónapra;

- 2019 utolsó hónapjának elején a hongkongi zászló alatt hajózó, a francia Total által bérelt, de a görög Navios cég által üzemeltetett Nave Constellation tanker esett áldozatul nyersolajat szállítva India felé: a támadók 19 tengerészt (18 indiai, 1 török) ragadtak el nem messze a kiemelten őrzött Egina fúrótoronytól - a legénység megmaradt hét tagja biztonságba juttatta a hajót;

- 2019. december 15-én a partoktól 130 tengeri mérföldnyire délre a Marshall-szigeteki bejegyzésü, az angolai Luandából Lomé felé tartó Duke olajtanker esett áldozatul: legénységéből az egyetlen nigériait leszámítva 20 indiai tengerészt raboltak el;

- egy héttel később a gaboni Libreville-nél egyidejüleg négy hajó fedélzetére léptek fegyveresek: egy helyi illetőségű kapitány életét vesztette, négy kínai halászt pedig elvittek magukkal;

- december 30-án éjszaka a kameruni Limboh olajtermináltól mindössze kétmérföldnyire a Happy Lady görög tankerről - 28 fős személyzete dacára - egy ukrán, két Fülöpszigeteki és öt görög polgárt raboltak el, egyet pedig megsebesítettek, ezzel együtt csak decemberben 57 fö esett a támadások áldozatul;

2 Piracy and Armed Robbery against Ships, Annual Report, 01. January - 31. December 2019. ICC-IMB. https:// www.icc-ccs.org/reports/2019_Annual_Piracy_Report.pdf (Letöltés időpontja: 2020. 01. 14.)

3 A sikeres és a sikertelen támadásokat becslések szerint az esetek felében nem jelentik számos okból: az jelentősen megemelné a biztosítási és a biztonságra fordítandó költségeket, miközben a vizsgálatok idejére visszatartott hajó kiesése akár napi 20-30 ezer dolláros veszteséget is jelenthet az üzemeltetőnek, illetve kényelmetlen kérdések merülhetnek fel a legénységgel, útvonalválasztással vagy rakománnyal kapcsolatban is. 
- az új évben egy lagosi gázipari cég üzemeltette Ambika kotróhajó a Ramosz folyó torkolatánál szenvedett el támadást: a súlyos tüzharcban a hajó biztonsági személyzetéből négyen életüket vesztették, ketten megsebesültek, két orosz és egy indiai állampolgárt pedig így is elraboltak. ${ }^{4}$

\section{A TENGEREK JELENTŐSÉGE}

A tengeri szállítmányozás jövedelmezősége jelentős kapacitásfejlesztést hozott az új évezredben, és a 2007/2008-as válság hatásait kiheverve a szektor fokozatosan újra erőre kapott. Napjainkban a világkereskedelem mintegy 90\%-a és az energiaellátáshoz szükséges nyersanyagok $65 \%$-a is hajókon ér célt. A leginkább használt gazdasági jelentőségű tengeri útvonalakat az 1. ábra mutatja.

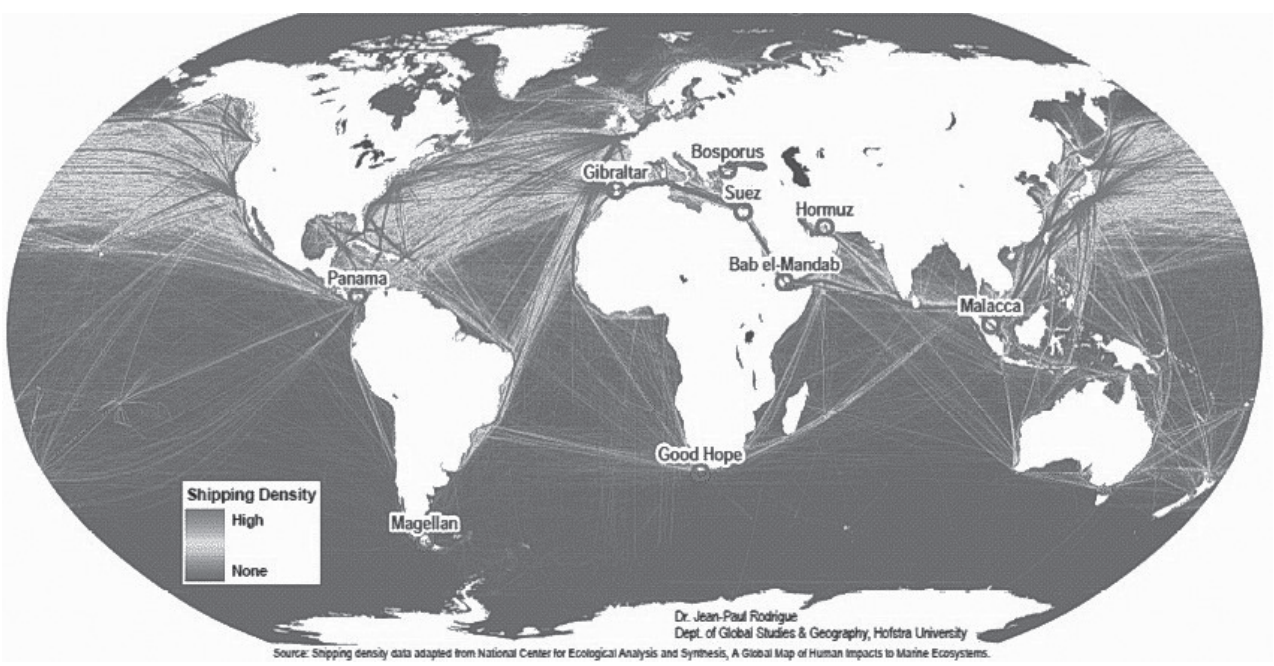

1. ábra A nemzetközi kereskedelmi hajózási útvonalak és kihasználtságuk

Afrika 38 tengerparti, illetve szigetállama 52 nemzetközileg jelentősebb kereskedelmi kikötővel rendelkezik, melyeken a Föld tengeri szállítmányainak 6\%-a halad át. A kontinens relatív súlytalanságát mutatja, hogy a világ hajóinak mindössze 1,2\%-a (BRT-ban 0,9\%-a) ezeknek az államoknak és/vagy polgárainak a tulajdona, miközben a kontinens nyersanyagexportjának és késztermékimportjának $90 \%$-a a tengereken keresztül zajlik. ${ }^{6}$

4 Four Dead, Three Kidnapped in Nigerian Pirate Attack. The Maritime Executive, 05. 01. 2020. https://www. maritime-executive.com/article/four-dead-three-kidnapped-in-nigerian-pirate-attack (Letöltés időpontja: 2020. 01. 20.)

5 Jean-Paul Rodrigue: Maritime Routes and Strategic Passages. In: Jean-Paul Rodrigue: The Geography of Transport Systems. Routledge, New York, 2020. https://transportgeography.org/wp-content/uploads/Map_Strategic_ Passages.pdf (Letöltés időpontja: 2020. 01. 10.)

6 Review of Maritime Transport 2018. United Nations Conference on Trade and Development. https://unctad.org/ en/PublicationsLibrary/rmt2018_en.pdf (Letöltés időpontja: 2020. 01. 10.) 
Alternatívája lehet a közúti, vasúti vagy légi szállítás, ám a hajózás mellett szól, hogy nagy tömegű áru célba juttatásának a legolcsóbb módja, ${ }^{7}$ relatíve kis energiafelhasználással, ellene szól viszont viszonylagos lassúsága és a szükséges kiszolgáló infrastruktúra költségessége, a rakodási idő nem ritka elhúzódása. ${ }^{8}$ Szintén nem elhanyagolható szempont, hogy a tengerek és szorosok, csatornák a nemzetközi jog szerint garantáltan szabadon hajózhatók, nem kell határok sorát átlépni. Igaz, az államoknak vannak nevesített jogaik például a parti vizeiken (a parttól számítva 12 tengeri mérföldön ${ }^{9}$ belül), a csatlakozó övezetekben (további 12 tengeri mérföldes sávban), illetve az ún. kizárólagos gazdasági övezetekben. ${ }^{10}$

A tengeri incidensekkel éppen ezért számos nehézség adódik: hatalmas, formális ellenőrzés nélküli területről van szó, ami nem zárt, ezért könnyü be- és kilépni (szigetek, kikötők, tagolt partvonalak segíthetik az elrejtőzést), miközben nagyszámú úszó objektum van mozgásban. Ráadásul a világ nem minden régiójában teljes a radarlefedettség, vagy van légi felderítési kapacitás, a technikai korlátok mellett pedig számításba kell venni - ha van is potens reagáló erő - az időjárást és a hatalmas távolságokat. A nemzetközi együttmüködés és az államközi/szervezetközi információmegosztás ezért kulcsfontosságú.

\section{TENGERI TERRORIZMUS}

A terrorizmusra az államok politikai megfontolásai és érintettségük mássága miatt sincs mindmáig egységes és elfogadott definíció, de a tengeren is sor került - nem nagy számban - egyértelmüen terrorcselekményként azonosítható eseményekre. Napjainkban is látható, ahogy képeken és videókon a Hamasz, a Hezbollah vagy a Boko Haram harcosai pózolnak felfegyverzett gyorsjáratú csónakokkal vagy búvárfelszerelésben. Bár valós fenyegetést és képességet jelenítenek meg, ezt azonban még jobbára inkább propagandacélzattal teszik. ${ }^{11}$

Potenciális célpontok lehetnek tengeri terrortámadásokhoz:

- katonai járművek (kiemelten a repülőgép-hordozó hajók és atom-tengeralattjárók);

- olajat és cseppfolyósított földgázt szállító tankerek;

- teherszállító hajók;

- kompok és utasszállító hajók;

- kikötői létesítmények;

- csatornák és tengerszorosok;

- tengeri létesítmények (elsősorban a tengeri olajfúró tornyok és vezetékek).

Vonzó lehetőség lehet ilyen nagy értékü és fontos célok támadása számos okból:

- izolált célpontok (kisebb az esély, hogy sikerül elmenekülniük, illetve nehéz a segítségükre sietni);

- tömeges áldozatszedés (veszteségokozás vagy túszszedés által);

\footnotetext{
7 Így elsősorban nem sürgős rendeltetésủ anyagok, tömegáruk, fütőanyagok, nyersanyagok, építőanyagok, késztermékek szállítására alkalmas. Lengyel Tamás (szerk.): Közlekedésföldrajz. 17. http://geografus.elte.hu/ web/tananyag/3/ipar/gy/kozlfoldrajz.pdf (Letöltés időpontja: 2020. 01. 12.)

${ }^{8}$ Érzékeny technológiájú, nagy értékủ eszközök és romlandó áruk esetében ezért is megfontolandó más szállítási módok választása. Ugyanakkor a kevés tengeri/folyami baleset és támadás miatt biztonságos, és nem mellesleg a környezetet - mértékét tekintve - relatíve kevésbé terheli.

91 tengeri mérföld $=1,852 \mathrm{~km}$.

${ }^{10}$ A tengerjog szokásjogi alapon müködött az 1958-as genfi ENSZ-konferenciáig, melynek során öt egyezményt fogadtak el. 1982-ben egy új átfogó egyezmény váltotta fel, illetve egészítette ki ezeket.

${ }^{11}$ Michael D. Greenberg et al.: Maritime Terrorism - Risk and Liability. RAND Corporation, 2006. https://www. rand.org/content/dam/rand/pubs/monographs/2006/RAND_MG520.pdf (Letöltés időpontja: 2019. 12. 20.)
} 
- jelentős anyagi károk okozása (az üzemeltetőnek, a tulajdonos országnak, a szektornak);

- a kereskedelem zavarása (stratégiai hatás);

- korlátozott válaszlehetőség (nehéz megközelítés, speciálisan felkészült erők kellenek);

- médianyilvánosság.

Az ilyen jellegü célpontok elleni támadások mégis meglehetősen ritkák, ami több okra vezethető vissza:

- ismeretek, képességek hiánya (hajózás, kikötői létesítmények, biztonsági intézkedések);

- hozzáférés nehézségei (a hajóhoz/kritikus infrastruktúrához, azok lezárt területeihez);

- költségigényes (szemben a szárazföldön végrehajtható támadások többségével);

- távolságok (a müveleti bázis és a célpont viszonylatában);

- idegen közeg (szemben a jól bevált szárazföldi akciókkal);

- hatékony nemzetközi együttmüködés és ellenlépések megléte.

A tengeri közlekedést és kereskedelmet ezért relatíve kevés politikai-ideológiai motiváltságú terrortámadás érte: ilyen események voltak a Santa Maria személyszállító és az Achille Lauro üdülöhajó eltérítése 1961-ben, illetve 1985-ben, a támadás a pireuszi kikötőben a City of Poros üdülőhajó ellen 1988-ban, valamint az Avrasaya komp ellen 1996-ban. 2000-ben az amerikai Sullivan elleni sikertelen merényletböl tanulva az al-Kaida öngyilkos motorcsónakjai már eredményesek voltak az amerikai Cole rombolóval, majd 2002-ben a Limburg olajtankerrel szemben. 2004-ben a zsarolásnak nem engedő hajózási társaságnak üzenetül a Fülöp-szigeteki Abu Szajjaf csoport a Superferry 14 kompot egy időzített improvizált robbanószerkezettel süllyesztette el, megölve 116 embert. 2004 márciusában konténerben utazva szivárgott be két öngyilkos akcióra készülő fegyveres az izraeli Asdód kikötőjébe, 2008 novemberében pedig a három napig tartó terroristaőrjöngésre a 10 fegyveres támadó a tenger felöl érkezett az indiai Mumbaiba. 2010 júliusában az M. Star tankert érte csónakos bombatámadás. 2014 szeptemberében pakisztáni tengerészek egy csoportja próbálta megkaparintani a Zulfikar fregattot, hogy aztán gyakorlatozó indiai és amerikai hadihajók ellen rakétatámadást végezzenek.

A tengeri terrorizmus körébe sorolható megvalósult vagy megkísérelt cselekmények: a vízfelszíni és a kikötői olajterminálok elleni támadások (Irak - 2004, Líbia - 2016), a hadihajókra partról páncéltörö rakétával indított rálövések (Egyiptom - 2015) és a jelenleg zajló jemeni polgárháború kapcsán az improvizált aknák, távirányítású robbanócsónakok és szabotázs alkalmazása a szaúdi és emirátusi kereskedelmi hajók és olajlétesítmények ellen.

A 2001. szeptember 11-i stratégiai terrortámadás, a Cole hadihajó és a Limburg tanker elleni akció, az al-Kaida ambíciói rádöbbentették az illetékeseket a tengeri szállítás sebezhetőségére is, melynek nyomán számos nemzetközi és nemzeti intézkedés született rövid időn belül. Előbbire példa az ENSZ Nemzetközi Tengerészeti Szervezete (International Maritime Organization-IMO) által 2002-ben kimunkált és 2004-ben életbe léptetett nemzetközi rezsim (International Ship and Port facility Security - ISPS - Code), mely egy átfogó, gyakorlatilag univerzális szabályozás a hajózás és a hozzá kapcsolódó létesítmények és tevékenységek biztonsági szempontú egységesítésére. Az azóta eltelt időszakban a legfontosabb feladat ezen elöírások egységes érvényesítése a hajók és a kikötők biztonsága érdekében - hiányosságok és sebezhetőség felmérése, ezek fényében pedig biztonsági tervek kidolgozása, szükséges intézkedések megtétele, képzések és gyakorlatok megszervezése a rendszer tesztelésére stb. ${ }^{12}$

\footnotetext{
${ }_{12}$ Fivos Andritsos: Port Security \& Access Control - A systemic approach. Conference Paper, 07. 2013. https:// www.researchgate.net/profile/Fivos_Andritsos/publication/249009738_Port_Security_Access_Control_a_ Systemic_Approach/links/00b7d51e287817956d000000/Port-Security-Access-Control-a-Systemic-Approach. pdf (Letöltés időpontja: 2020. 07. 28.)
} 


\section{TENGERI KALÓZKODÁS}

Szükséges élesen különválasztani a jelenséget a terrorizmustól, jellegében és anyagi motiváltságát illetően is. A tengeri kalózkodás tulajdonképpen sose szünt meg, támadások egyes régiókban jellemzően előfordultak, de a hidegháborút követően megjelenő gyenge és bukott államoknak a vizeik feletti kontrollja hiányában a kalóztámadások gyakorisága jelentősen megnőtt föleg Indonézia térségében és a Malaka-szorosban, Banglades part menti vizein, Latin-Amerika egyes régióiban és Afrika válságos zónái közelében. A kereskedelmi célú hajóforgalom nagymértékü felfutása mellett annak sebezhetősége és a relatíve alacsony rizikó is mellette szólt: a parti és a kikötői biztonság hiányosságai az államok erre fordítható forráshiányával együtt, a korrupció, az igazságszolgáltatás gyakran felmentéssel záruló ítélkezési gyakorlata, a könnyüfegyverek (sőt, géppuskák és kézi páncéltörő gránátvetők) globális proliferációja. A szegénység, a politikai viszonyok rendezetlensége is ösztönzője volt a kalózkodás felfutásának. Így míg 1994-1999 között 209, 2000-2006 között már átlagosan évi 352 regisztrált támadás történt. Az IMB adatai szerint 2006-ban Nigéria térségében az esetek 5\%-a, Szomáliánál 4\%-a fordult elő - miközben Indonézia és Banglades 21, illetve $20 \%$-ban részesedett. ${ }^{13}$

A polgárháborús anarchiába süllyedt Szomália esetében a halászok, tengerészek számára ez egy menekülési út volt: egyrészt a megélhetés miatt, másrészt ellenreakcióként, mivel más államok az ország partjainál a vizeket lehalászták és szemétlerakóként használták. ${ }^{14} \mathrm{~A}$ sikereken felbátorodva az 1990-es években még amatőr szomáli kalózok 2000 kilométerre a honi partoktól is támadásokra szánták el magukat, egészen Tanzánia északi vizei és India nyugati partvonala magasságáig. A hajózás biztonságának ilyen mértékü veszélyeztetése - és az emiatt emelkedő szállítási költségek - a nemzetközi közösséget cselekvésre kényszerítették. ${ }^{15}$

A szomáliai kalóztámadásokat sikerült semlegesíteni. Ebben szerepet játszott a fokozott nemzetközi haditengerészeti jelenlét, ${ }^{16}$ mert a támadásokra a hadihajók fedélzetéről helikopterekkel gyorsreagálású eröket küldtek a bajba jutott hajók megsegítésére. Fokozatosan egy biztonsági folyosó alakult ki a Vörös-tenger felé, melyen már gyakorlatilag kockázatmentesen haladhattak a konvojba szerveződött szállítóhajók. A kalóztámadások visszaszorítását elősegítette az is, hogy egyes hajózási vállalatok igénybe vettek magán biztonsági cégeket

${ }_{13}$ Piracy and Armed Robbery against Ships, Annual Report, 01. January - 31. December 2006. ICC-IMB. https:// www.icc-ccs.org/reports/2006_Annual_IMB_Piracy_Report.pdf (Letöltés időpontja: 2019. 12. 20.)

14 Amy Goodman: Analysis: Somalia Piracy Began in Response to Illegal Fishing and Toxic Dumping by Western Ships off Somali Coast. Democracy Now, 14. 04. 2009. https://www.democracynow.org/2009/4/14/analysis_ somalia_piracy_began_in_response (Letöltés időpontja: 2019. 12. 29.)

${ }^{15}$ Az ukrán SC TOMEX cég által üzemeltetett (belize-i zászlóval hajózó és egy panamai cég által birtokolt) Faina szállítóhajó eltérítése 2008 szeptemberében nagy nemzetközi felhördülést keltett: fedélzetén ugyanis 33 darab T-72 harckocsi mellett páncéltörő és légvédelmi fegyverek tartottak a hivatalos végfelhasználó, Kenya felé - azok célállomása azonban valójában Dél-Szudán volt. A kalózok kezdetben 35 millió amerikai dollárt követeltek a 21 orosz és ukrán túsz és a hajó átadásáért, ezt több szakaszban sikerült 3,2 millióra lealkudni. A hajót röviddel elfoglalása után a térségben tartózkodó amerikai és orosz hadihajók követték, így a szállított fegyverek legalább nem kerülhettek rossz kezekbe. A kalózok végül 2009 februárjában elengedték foglyaikat és elhagyták a hajót.

16 Az ENSZ 2008-as felkérésére reagálva a NATO a következő évben indította útjára biztonsági múveletét (Operation Ocean Shield), az EU pedig a sajátját (Operation Atalanta), illetve egy többnemzeti kötelék is létrejött (Combined Task Force-151), emellett több állam (például Ausztrália, Oroszország, Japán, Kína, India) döntött önálló, de a többi művelettel összehangolt haditengerészeti jelenlét mellett. Varga Attila Ferenc: Nemzetközi küzdelem a szomáliai kalózkodás ellen. http://mhtt.eu/hadtudomany/2011/2011_elektronikus/2011_e_14.pdf(Letöltés időpontja: 2019. 12. 29.) 
(Private Maritime Security Company) tanácsadásra - például az útvonal tervezéséhez és/vagy a legénység képzésére, de akár 3-4 fö fegyverest (Maritime Security Operator) vagy felfegyverzett kísérőhajókat is igényelhettek tőlük. A mogadishui kormány lassan kiterjesztette ellenőrzését a kalózok szárazföldi bázisaira, a támadásra használható hajókat pedig megsemmisítették. A kalózkodás így gyakorlatilag ellehetetlenült. Ez a látványos siker azonban nem szüntette meg a kalózkodás jelenségét, sem az azt kiváltó problémákat, csupáncsak súlypontja helyeződött át a nyugat-afrikai vizekre.

Az előző évi 180-nal szemben 2018-ban világszerte 201 incidenst jelentettek: ${ }^{17} 143$ esetben fel is jutottak a hajókra a támadók, hat esetben eltérítették a vízi járművet, 18-szor történt rálövés, míg 34-szer sikertelen volt a támadási kísérlet. Az esetek negyedében tankerhajó volt a megtámadott, 18 esetben pedig konténerszállító. Mindezen események során 141 föt ejtettek túszul, 83 föt raboltak el váltságdíj reményében, nyolcan sérültek meg. Földrajzi eloszlásukat tekintve a Guineai-öböl jelenleg a világ „legkalózveszélyesebb” térsége; az indonéz szigetvilág a másik veszélyzóna, illetve a közállapotokkal összefüggésben Banglades és Venezuela part menti vizei.

\section{A GUINEAI-ÖBÖL}

Az utóbbi években lecsengett szomáliai kalózkodáshoz és a jemeni húti felkelöknek a szaúdi és az emirátusi hajók elleni meglepő támadásaihoz képest kevés globális sajtóvisszhangot váltanak ki a nyugat-afrikai vizek eseményei. Bár a térség a főbb hajózási útvonalak többségétől viszonylag távol esik, jelentősége így sem lebecsülhető, a Guineai-öbölben tapasztalható aggasztó tendenciák ellenére mégis visszafogott a nemzetközi reakció.

A kriminális cselekmények elsősorban - a Boko Haram-jelenséggel is küszködő Nigériához köthetőek, amely viszont egy müködő állam, mely autoritását (elméletileg) képes érvényesíteni. Az itteni kalózkodás fő kibocsátója a függetlenségre, vagy legalábbis az olajbevételek térségbe történő fokozottabb visszaforgatására törekvő Niger-delta régió: a nemzetközi olajtársaságok és a nigériai hatalmi elit kisajátította profitból az ogoni és az ijo őslakosság keveset, az olajkitermeléssel járó káros következményekből annál többet érzékelve tüntetésekbe, majd ezek hatástalansága miatt radikalizálódva fegyveres küzdelembe fogott a központi kormány és a külföldi olajcégek ellen. Létrehozták a Niger-delta Felszabadítási Mozgalmat (Movement for the Emancipation of the Niger Delta), mely 2005-töl a 2009-es tüzszünetig módszeresen pusztította az olajipari létesítményeket. A küzdelem vezetőinek egy része kiegyezett a központi kormánnyal, hogy a továbbiakban pénzért ők védelmezik az olajkutakat és vezetékeket. ${ }^{18}$ A felkelök egy része ellenben folytatta a harcot, és 2010 -től mindinkább kalóztámadásokat hajtottak végre. Minthogy ezek kezdetben inkább partközelben és helyi érdekeltségek ellen zajlottak, ezért ez nem is érte el egy nemzetközi válaszreakció ingerküszöbét. Lokális kezdeményezések voltak ugyan (ilyen volt 2011-2012-ben Benin és Nigéria közös müvelete (Operation Prosperity), de máskor az államközi feszültségek éppen ellehetetlenítették ezt - mint például Kamerun és Nigéria ellentéte a Bakassi-félsziget miatt. ${ }^{19}$

\footnotetext{
17 Piracy and Armed Robbery against Ships, Annual Report, 01. January - 31. December 2018. ICC-IMB. https:// www.icc-ccs.org/reports/2018_Annual_IMB_Piracy_Report.pdf(Letöltés időpontja: 2019. 12. 20.)

${ }^{18}$ Bálint Tamás - Zsitkó Mariann: A Niger-delta Felszabadítási Mozgalom (MEND). In: Kiss Álmos Péter (szerk.): Afrikai terrorista és szakadár szervezetek. HVK Tudományos Kutatóhely - NKE, Budapest, 2016, 319-339.

19 A terület hovatartozása az 1960-as függetlenség óta vitatott, és noha formailag az abujai kormány lemondott róla, a nigériai alkotmányban továbbra is az országhoz tartozónak említik a régiót. Kamerun ezt nehezményezi, miközben helyi szeparatistákkal is meg kell küzdenie az olajban gazdag félszigeten.
} 
A teljes képhez ugyanakkor hozzátartoznak a mindenfajta politikai motiváció nélküli, csupán nyereségvágyból elkövetett akciók is: az 1990-es években a horgonyzó hajók fedélzetéről történő kis értékű lopásoktól, „,besurranó” tolvajlásokból indult, majd szervezettebb formát öltve macsétákkal, majd mind komolyabb löfegyverekkel végrehajtott rablásokig jutottak a bủnbandák. A korrupt hivatalnokok és az alulfizetett fegyveres erők bevont tagjai által mind kiterjedtebb hálózatok épültek ki, és egyre inkább a tankerek elrablása lett a cél. Az átnevezett és átlobogózott hajók a továbbiakban a bünözői-állami hibrid bünszervezeteket szolgálták, míg a rakomány - jellemzően kőolaj - nyersen vagy primitív partközeli feldolgozók által került a feketepiacra.

Az olajárak mélyrepülése - és a szomáliai példa - nyomán az utóbbi években a váltságdíjért elkövetett emberrablás került elötérbe. Az elraboltakat ritkábban tartják a zsákmányolt, átnevezett és átfestett hajókon, vagy a gyorsjáratú csónakokat a nyílt vizekre szállító ún. anyahajókon, inkább gyorsan a partra juttatják és mélyebben a szárazföldön rejtik el őket a váltságdíjról szóló tárgyalások idejére, ami néhány naptól akár 3-4 évig is terjedhet. A higiéniai viszonyok, minimális étkezés, az orvosi ellátás hiánya, a fenyegető bánásmód miatt a túszok közül többen nem érik meg a szabadulást, negyedük pedig a későbbiekben tartós mentális és pszichológiai problémákat mutatott. ${ }^{20}$

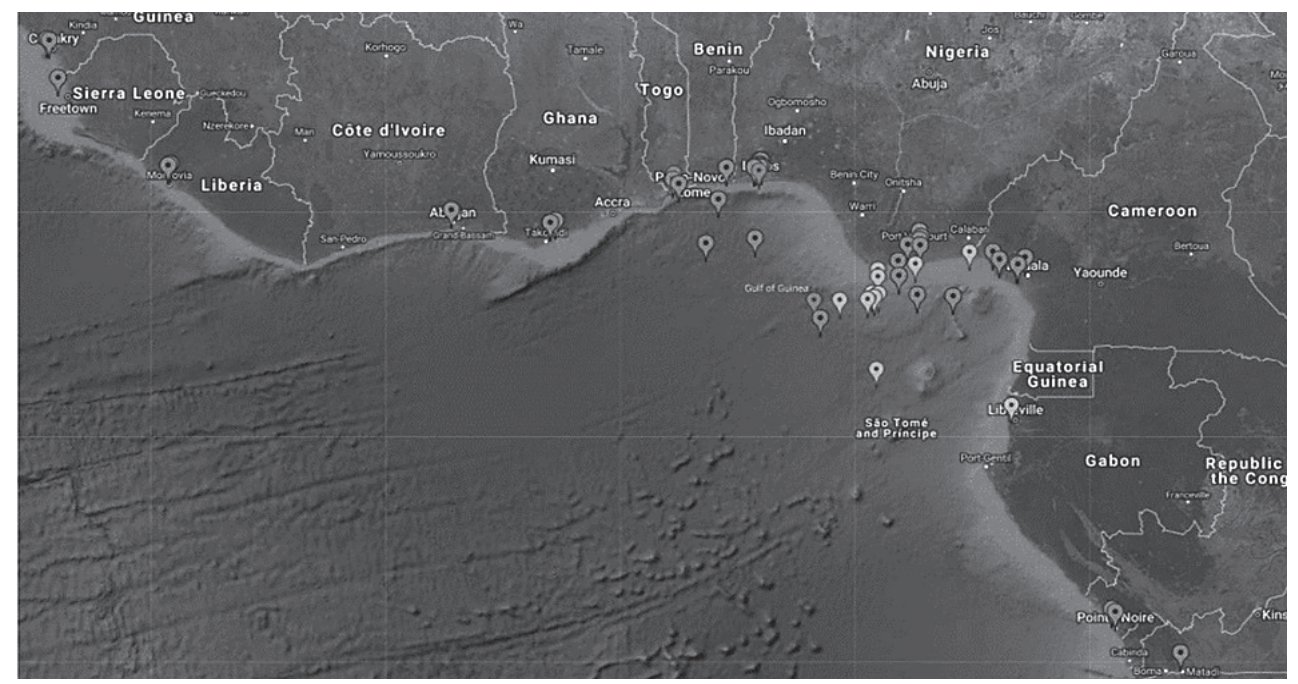

2. ábra Hajók elleni támadások a Guineai-öbölben ${ }^{21}$

A minden szférát és szintet átszövő korrupció és személyi összefonódások miatt csak strukturált kleptokráciaként leírt nigériai rendszerben komoly felbolydulást okozott 2015 áprilisában Muhammadu Buhari elnökké választása, illetve az olajárak mélyrepülése: felrúgva a 2009-es megállapodást a Niger-delta lázadóival - akik a megbékélés áraként addig a térség olajlétesítményeit biztosították a bevételekből való részesedésért -, most ezek a

${ }^{20}$ Olivia Konotey-Ahulu: Pirates Now Prefer Human Hostages Over Ships And Cargo. Bloomberg, 20. 12.2019. https://www.bloomberg.com/news/articles/2019-12-20/pirates-now-prefer-human-hostages-over-ships-andcargo (Letöltés időpontja: 2020. 07. 28.)

${ }^{21}$ Piracy and Armed Robbery Against Ships, Report for the Period, 01. January - 31. December 2019., 61. ICCIMB. https://www.icc-ccs.org/reports/2019_Annual_Piracy_Report.pdf(Letöltés időpontja: 2020. 01. 30.) 
pénzek (amnesty stipends) megcsappantak, másrészt eljárások indultak a volt gerillák vezetői ellen. Ellenreakcióként létrejött a Niger Delta Avangers nevü formáció, mely támadásaival elérte a olajkitermelés felére, napi 1,1 millió hordóra történő zuhanását. 2016 áprilisában a szervezet három hét alatt 15 támadást hajtott végre, 22-én pedig gyakorlatilag hadat üzent a haditengerészetnek. ${ }^{22}$ Különösen a deltavidék délnyugati része (Brass régió) és a Port Harcourt előtti vizek (Bonny régió) voltak a legveszélyeztetettebbek, de a kalózok mindinkább kiterjesztették müveleti területüket a parti vizektől akár 150-200 tengeri mérföldre is.

Nigériában máig súlyos hiányosság, hogy nincs parti őrség, így a feladat és a felelősség - a megelőzéstől kezdve az intervencióig és a bünvádi eljárások elindításáig - számtalan szervezet között oszlik meg. Az eredményességhez a korruptként leírt haditengerészet mellett a Nigériai Tengerészeti Rendőrség (Nigerian Maritime Police), a Nigériai Tengerészeti Adminisztrációs és Biztonsági Ügynökség (Nigerian Maritime Administration and Safety Agency), a Gazdasági és Pénzügyi Büncselekmények Bizottsága (Economic and Financial Crimes Commission), a Nemzeti Drogellenes Hivatal (National Drug Law Enforcement Agency) és az Ügyészségi Igazgatóság (Directorate of Public Prosecutions) együttmüködésére lenne szükség. Többnyire ezek a szervezetek delegálnak egy vagy több kísérőt a hajókra, mivel a nigériai belső jog nem engedi külföldi cégek fegyvereseinek a jelenlétét a hajókon és kikötőkben. Ezzel a jogi szabályozással viszont a hajósok kiszolgáltatottak is a hatóságoknak, melyek egyes tagjai átadják az információkat (útvonal, személyzet, szállítmány) a lesben álló bünbandáknak. ${ }^{23}$

És itt számításba kell venni azt is, hogy a mai polgári használatú hajók személyzete fegyvertelen, emellett képzetlen is ilyen támadások elhárítására. Igaz, az igényekre válaszul számos megoldás született: a hajók egy lezárható részéből ún. citadellát alakítanak ki, ${ }^{24}$ nem halálos eszközök sorát is kifejlesztették a kalózok távol tartásához vagy ideiglenes bénításához, mint például a nagy erejü távirányítású vízágyúk, elektromos szögesdrót akadályok vagy vakításra szolgáló lézerek - ezek azonban nem mindig bizonyultak hatékonynak. A fegyverbirtoklás és -használat a személyzet vagy a védelemre alkalmazott zsoldosok részéről viszont felvet számos jogi aggályt, és egyes államok ennek lehetőségét inkább ki is zárják.

Az érintett 22 nyugat- és közép-afrikai állam - érezve a helyzet tarthatatlanságát, illetve engedve a nemzetközi nyomásnak ${ }^{25}$ - 2013 júniusában Yaoundéban kimunkálta a kalózkodás, a csempészet és az illegális halászat elleni fellépés módját, ${ }^{26}$ valamint döntött az együttműködés és az információmegosztás hatékonyabbá tételéről, illetve a nemzeti

22 Steffen Dirk: A Niger Delta militant group declares war on the Nigerian Navy. Center for International Maritime Security, 30. 04. 2016. http://cimsec.org/niger-delta-militant-group-declares-war-nigerian-navy/24958 (Letöltés időpontja: 2020. 01. 29.)

${ }^{23}$ Az államhatalmi szféra, a fegyveres erők és a bűnözői kartellek összejátszását mutatja, hogy több esetben a nigériai haditengerészet admirálisai és a kormányzók is a vádlottak padjára kerültek. Stephen Starr: Maritime Piracy on the Rise in West Africa. Combating Terrorism Center Sentinel, 04. 2014. https://ctc.usma.edu/maritime-piracyon-the-rise-in-west-africa (Letöltés időpontja: 2019. 12. 29.)

${ }^{24}$ Mely egy pánikszobához hasonlóan nyújt menedéket a támadás idejére, megfelelő víz- és élelemtartalékkal, szürt levegővel és elsősegélycsomaggal, valamint kommunikációs eszközökkel - emellett lehetséges innen a hajógépek leállítása is.

25 2011-ben az ENSZ BT 2018. sz. határozata a térség államait fokozottabb együttmüködésre ösztönözte, míg 2012-ben a 2039. sz. határozat a nemzeti és a regionális fellépés fontosságát és a jogi feltételek megteremtését szorgalmazta.

${ }^{26}$ Code of Conduct Concerning the Repression of Piracy, Armed Robbery against Ships and Illicit Maritime Activity in West and Central Africa. 25. 06. 2013. http://www.imo.org/en/OurWork/Security/WestAfrica/Documents/ code_of_conduct $\% 20$ signed $\% 20$ from $\% 20$ ECOWAS\%20site.pdf (Letöltés időpontja: 2020. 07. 01.) 
tengerészeti stratégiáik jobb összehangolásáról. A szerződés nyomán létrejött konstrukció a Yaoundéi Tengeri Biztonsági Struktúra elnevezéssel ismert (Yaoundé Architecture for Maritime Safety and Security). Itt, a kameruni fővárosban megalakult egy stratégiai szintű, Interregionális Koordinációs Központ (Inter-regional Coordination Centre-ICC), valamint a két afrikai regionális szervezetnek (ECOWAS ${ }^{27}$ és ECCAS ${ }^{28}$ ) is egy-egy regionális jelentöközpontja. ${ }^{29}$ Ezeket - öt zónát kialakítva ${ }^{30}$ - többnemzeti, müveleti-taktikai koordinációs központok, illetve 21 - folyamatos szolgálatot adó - taktikai szintü állomás szolgálja ki. Feladatuk a közép-afrikai államok esetében $1225000 \mathrm{~km}^{2}$ vízfelület és több mint $3300 \mathrm{~km}$ partvonal ellenőrzése, miközben a radarlefedettség mindmáig erösen hiányos. Ugyanakkor zavart okoznak az egymást részben átfedő regionális szerveződések, melyeket olykor egyegy állam igyekszik dominálni, és a sok koordinációt elősegíteni hivatott központ sokszor éppen a hatékony együttmüködés rovására müködik.

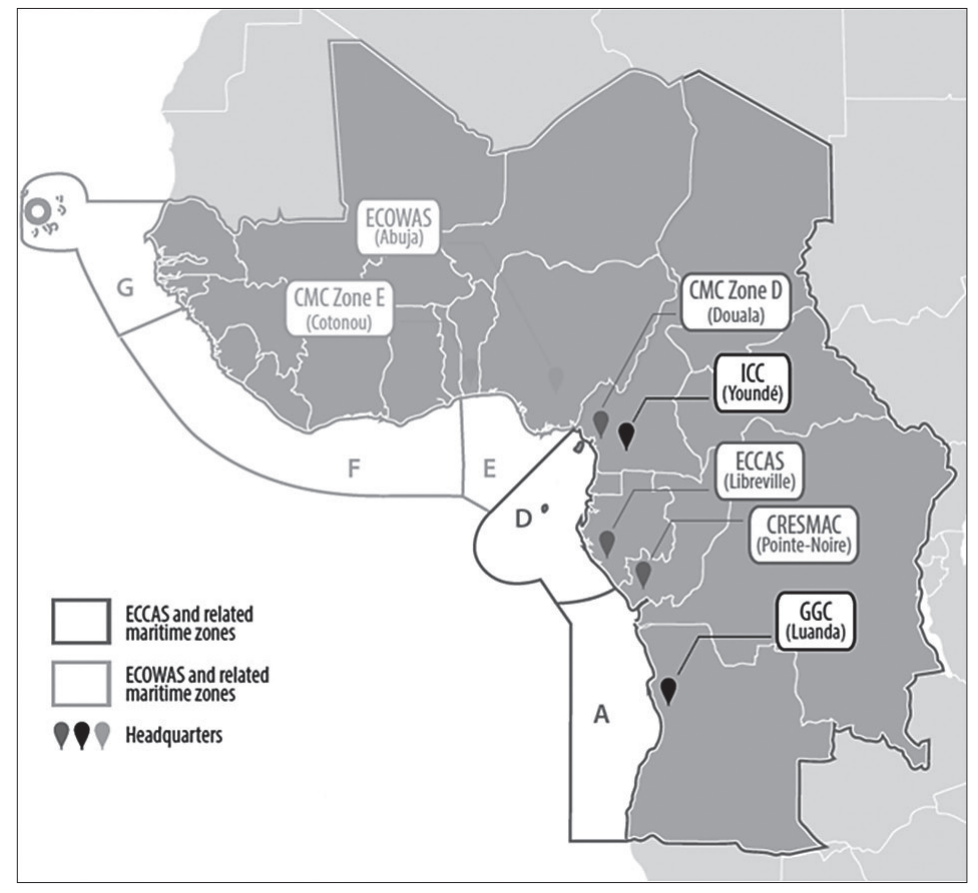

3. ábra A Yaoundéi Tengeri Biztonsági Struktúra rendszere ${ }^{31}$

${ }^{27}$ Economic Community of West African States - Nyugat-afrikai Államok Gazdasági Közössége.

${ }^{28}$ Economic Community of Central African States - Közép-afrikai Államok Gazdasági Közössége.

${ }^{29}$ A nyugat-afrikai (Centre Régional de Sécurité Maritime de l'Afrique de l'Ouest-CRESMAO) az elefántcsontparti Abidjanban, a közép-afrikai pedig (Centre Régional de Sécurité Maritime de l'Afrique Centrale - CRESMAC) a Kongói Köztársaságban, Pointe Noire-ban van.

${ }^{30}$ Az 1983-ban létrejött ECCAS tagállamai - Angola, Kongói Demokratikus Köztársaság, Kongói Köztársaság, illetve Kamerun, Egyenlítői-Guinea, Gabon, São Tomé és Príncipe - alkotják az A és a D zónát. Az 1975-ben megalakult ECOWAS három zónát fed le: E - Nigéria, Benin, Togo, Niger; F - Ghána, Elefántcsontpart, Burkina Faso, Sierra Leone, Libéria, Guinea; G - Zöld-foki Köztársaság, Szenegál, Gambia, Bissau-Guinea, Mali.

${ }^{31}$ EU Maritime Security Factsheet: The Gulf of Guinea. EU External Action, 29. 10. 2018. https://eeas.europa.eu/ headquarters/headquarters-homepage/52490/eu-maritime-security-factsheet-gulf-guinea_en (Letöltés idöpontja: 2020. 08. 04.) 
A térség vizeit zónákra osztó szervezeti rendszer mellett szükséges volt az eljárások kidolgozása is, ezért a következő évben a Nemzetközi Tengerészeti Szervezet (IMO) összefoglalta a segítség irányait, ${ }^{32}$ miután már 2006 óta dolgozott a parti őrségre tartozó feladatok hatékonyabb államközi összefogásán. ${ }^{33} 2011$ októberében Addisz-Abebában az Afrikai Unió védelmi minisztereinek találkozóján döntés született egy Tengerészeti Információs és Koordinációs Sejt (Maritime Information and Coordination Cell) létrehozásáról, hogy áttekintsék és összehangolják az erőfeszítéseket. Ez a kiépített figyelőállomásokkal és jelentési rendszerrel együtt elméletileg lehetővé tenné, hogy önerőből reagálni tudjanak a majdan felállításra kerülő készenléti erők (African Standby Force), amint képességeik és készültségi szintjük lehetővé teszi.

Az erőfeszítések egyik eredményeként - felismerve a kontinens nemzetközi gazdaságikereskedelmi súlyának és érdekérvényesítő képességének fokozatos csökkenését - az Afrikai Unió 2012-ben tető alá hozta az Integrált Tengerhajózási Stratégiát. ${ }^{34} \mathrm{Ez}$ a dokumentum összefogottabb erőfeszítések révén 2050-re célul tüzi ki, hogy a partközeli vizek hatékonyabb ellenőrzésével visszaszorítsa az illegális tevékenységeket - például szennyezés, orvhalászat, kalózkodás, csempészet -, ezzel pedig megalapozza egy fenntartható „kék gazdaság” (blue economy) kialakítását, aminek eredményeként növelhető a lakosság jóléte és a kontinens versenyképessége.

A probléma azonban sokrétü. A térségben a legpotensebbnek a nigériai haditengerészet tünne, de a flotta fele folyamatosan müködésképtelen, míg a többi hajó az olajlétesítményeket őrzi - így gyakorlatilag nem maradt erő, mely gyorsan reagálhatna, ha a hatóságok bejelentést kapnak. ${ }^{35} \mathrm{Az}$ ország tengerészete a különböző rezsimek alatt folyamatosan elhanyagolt volt, a Nigéria mélytengeri ambícióit védeni hivatott legnagyobb hajó, a német gyártású Aradu fregatt 2017 óta a kikötőben vesztegel, mivel nincs forrás a hajó újbóli üzemképessé tételére. Az amerikai parti őrségtől örökölt két 1968-as gyártmányú, Hamilton-osztályú kutter már alig felel meg az igényeknek. A szűkös anyagi lehetőségekből kiindulva inkább kisebb, gyorsjáratú járőrhajókat és motorcsónakokat rendszeresítenek főleg francia, német, szingapúri, malajziai, vietnámi és helyi gyártóktól. A rendelések felfutását mutatja, hogy csak 2019-ben és 2020ban több mint 40 eszközt kaptak, illetve ugyanennyi beérkezését várják. Emellett mind több repülőeszközt szereznek be tengeri járörfeladatokra, mivel még az is komoly képességhiány.

A nigériai haditengerészet fellépését gyakran így is csak reaktívnak, defenzívnek és szimbolikusnak írják le. A ritka sikeres és nagyobb közfigyelmet kapott akciók egyike a Maximus tankerhez kötődik: 2016. február 11-én két csónakból 14 nigériai és ghánai kalóz kerítette hatalmába a dízelolajat szállító hajót az elefántcsontparti Abidjantól 70 mérföldnyire. A riasztást követően egy hadgyakorlaton a közelben tartózkodó amerikai Spearhead

${ }^{32}$ Implementing sustainable maritime security measures in West and Central Africa. IMO, 01. 2014. http://www. imo.org/en/OurWork/Security/WestAfrica/Documents/IMO\%20WCA\%20strategy\%20January\%202014.pdf (Letöltés időpontja: 2020.08.03.)

33 A Nyugat- és Közép-afrikai Hajózási Szövetség (Maritime Organisation of West and Central Africa - MOWCA) megegyezésével egy szándéknyilatkozat született a tárgyban: Memorandum of Understanding on the Establishment of a Sub-Regional Integrated Coast Guard Function Network. https://iea.uoregon.edu/treaty-text/2008-mousub regionalcoastguardnetworkwestcentralafricaentxt (Letöltés időpontja: 2020. 08. 03.)

342050 Africa's Integrated Maritime Strategy 2050 (AIMS 2050). African Union, 2012. https://cggrps.com/wpcontent/uploads/2050-AIM-Strategy_EN.pdf (Letöltés időpontja: 2020. 08. 03.)

35 Åse Gilje Østensen et al.: Capacity building for the Nigerian Navy: Eyes wide shut on corruption? U4 Issue 2018:4. Anti-corruption Resource Centre. https:/www.u4.no/publications/capacity-building-for-the-nigerian-navy-eyeswide-shut-on-corruption.pdf (Letöltés időpontja: 2020. 01. 26.) 
gyorsjáratú expedíciós szállítóhajó kezdte követni a tankert a ghánai vizekig, majd São Tomé gazdasági övezetében - annak beleegyezésével - a nigériai Okpabana kutter vette át a követést. Február 19-én végül Lagostól 300 mérföldnyire délre a hajóról megrohamozták a Maximust, de a fegyveresek egy része ekkor már valószínüleg egy „,anyahajóra” és egy kambodzsai zászlójú, velük együttmüködő kisebb olajtankerre szállt át - a tüzharcban egy kalóz életét vesztette, hatan fogságba kerültek. ${ }^{36}$

\section{KORLÁTOZOTT NEMZETKÖZI SZEREPVÁLLALÁS}

Bár a külföldi katonai jelenlét miatt 2016 májusában az Afrikai Unió Béke és Biztonsági Tanácsa 601. ülésén aggodalmát fejezte ki, de az önálló válságkezelő képességek hiányában, valamint kétoldalú megállapodások esetén nem sokat tehetnek: a pánafrikai szellemiséget felülírja a nyers realitás, vagyis hogy a hajózásnak nagyobb oltalmat, illetve a biztonsági erők képességépítéséhez és müködtetéséhez extra forrásokat csak a térségen kívüli hatalmak adhatnak.

Az Amerikai Egyesült Államok haderejének Afrikai Parancsnoksága (AFRICOM ${ }^{37}$ ) több formában is segíti a helyi biztonsági erőket. A security assistance keretében az öbölbeli államok és azok szervezetei közti információmegosztás, kooperáció és interoperabilitás van középpontban, a „train-and-equip programme” pedig a harcászati szintű képességépítést szolgálja kiképzés, anyagi források és felszerelés biztosításával. A két programot stratégiai szinten támogatni hivatott a biztonsági szektor átfogó reformját (security sector reform) elősegítő mentorálás, tanácsadás.

A 2008-ban útjára indított partnerségi program (Africa Partnership Station) által az amerikai haditengerészet ad többirányú segítséget, melynek négy pillére a képzés, az afrikai partnerszervezetek állományának professzionálissá tétele, a tengerészeti infrastruktúra fejlesztése és a reagálóképességek kiépítése. Mindezeket mobil kiképzőcsoportokkal és hadihajók kikötőlátogatásával segítik elő. A hatékony és jogszerü fellépést segítő projekt (Africa Maritime Law Enforcement Partnership - AMLEP) helybeni képzések mellett közös gyakorlatokat és mandátumában korlátozott müveleteket tesz lehetővé. ${ }^{38}$

Franciaország volt gyarmattartóként főleg a frankofón országokkal örizte meg kapcsolatait, és érdekeltségei védelmében 1990 óta folyamatosan fenntartja jelenlétét a térségben. Féléves rotációval - a Corymbe misszió keretében - legalább egy hadihajóval van jelen, változó prioritásokkal. Feladat az együttmüködés a Dakarban állomásozó francia szárazföldi és repülőalakulatokkal, a francia erők támogatása Elefántcsontparton, a francia állampolgárok evakuálása, ha az valahol szükségessé válik, valamint a kalózkodás és a bünözés elleni küzdelem.

Az Európai Unió Tengeri Biztonsági Stratégiája ${ }^{39}$ (EU Maritime Security Strategy) a 2014-es megszületése óta bekövetkezett változások - például Líbia mint állam összeomlása és a tengeren keresztül kialakult migrációs nyomás - nyomán 2018-ban revízió alá került,

${ }^{36}$ Steffen Dirk: West African navies coming of age? Center for International Maritime Security, 07. 03. 2016. http://cimsec.org/coming-of-age-of-the-west-african-navies/22919 (Letöltés időpontja: 2020. 02. 14.)

37 Africa Command.

38 Africa Maritime Law Enforcement Partnership (AMLEP) Program. United States Africa Comand. https://www. africom.mil/what-we-do/security-cooperation/africa-maritime-law-enforcement-partnership-amlep-program (Letöltés időpontja: 2020. 02. 10.)

39 European Union Maritime Security Strategy. 24. 06. 2014. Council of the European Union, 24. 06. 2014. http:// register.consilium.europa.eu/doc/srv?1=EN\&f=ST\%2011205\%202014\%20INIT (Letöltés időpontja: 2020. 03. 10.) 
és a konkrétabb lépéseket tartalmazó Cselekvési Tervben (Action Plan 2015-20) is megfigyelhetök hangsúlyeltolódások. A Guineai-öböl komplex problematikájára reagálva több, bár relatíve alacsony költségvetésü programot ${ }^{40}$ indított útjára a hatékonyabb interregionális információmegosztás és bünügyi együttműködés előmozdítására, illetve az ISPS-standardok megvalósítására. Az EU a fokozottabb szerepvállalásra való hajlandósága jutott kifejezésre a 2016-os Globális Stratégiában is, melyben mint a tengeri biztonság védnöke (,,EU as global maritime security provider") fogalmazza meg szerepét. ${ }^{41}$

\section{ÖSSZEGZÉS}

A korábbi évtizedekben jobbára fegyvertelen személyeknek a lehorgonyzott hajók fedélzetére történő fellopakodása készpénz és/vagy nagyobb értékű vagyontárgyak ellopása céljából volt jellemzö, illetve szervezettebb keretek között az olajtankerek megcsapolása történt az olaj illegális eladásához. 2014-től azonban, az olajárak esésével a hajók személyzetének elrablása és váltságdíjért történő szabadon engedése lett mindinkább elterjedt. A nigériai kormányzat hatékony fellépését nagyban gátolja a rendszerszintü és mindent átható korrupció, a politikával összefonódó banditizmus és a felkelőcsoportok miatti instabilitás. A helyi haditengerészet a fentebbi problémáktól is áthatottan, de a megfelelő képességek hiányában sem tud hatékony lenni. Az alulfinanszírozott biztonsági erők, az alacsony morál és presztízs miatt is összejátszanak a bünözőkkel információk átadásával, de akár maguk is pénzt szedhetnek a hajóktól „,az áthaladásért”. Az amúgy is gyenge államhatalom iránti alacsony közbizalom hosszú távon is ellehetetleníti a jelenség megszünését - így a biztonsági erőknek nyújtott jobb kiképzés, több pénz, több technika aligha jelenthet megoldást, amíg a szegénység és kilátástalanság a lakosságban ilyen mértékü. A többi állam a térségben nem rendelkezik számottevő tengerészeti kapacitással, a külföldi jelenlét pedig még mindig csak jelképes.

A tengeri biztonságot fenyegető erőszakos támadás nem új jelenség, de annak mértéke és formái már igen: a terroristák és a kalózok - eltérő motivációval és célokkal - de folyamatosan keresik, hogy lehetőségeikhez képest milyen új eljárásokat és eszközöket vethetnének be. Aggasztó opció a szervezett bünözői csempészet, a kalózkodás és a terroristacsoportok esetleges egymásra találása, együttműködése. A Latin-Amerikából Marokkó, Bissau-Guinea és Lagos rejtett átrakodóhelyeire érkező kokain a több évszázados karavánutakat használva jut Észak-Afrika, onnan pedig Európa kikötőibe - eközben bevételt jelent a csempészetet „oltalmazó” dzsihádista terrorista csoportoknak a Száhel övezetben. ${ }^{42}$

A Guineai-öböl államai parti felségvizeik hatékony ellenőrzésével azonban nemcsak a kalóztámadások okozta fenyegetést lehetne megszüntetni, de a szervezett bünözésre, illetve

${ }^{40}$ Ilyenek például: Gulf of Guinea Inter-Regional Network (GoGIN), Critical Maritime Routes Monitoring Support and Evaluation Mechanism (CRIMSON), Improving Port Facility Security in West and Central Africa, Seaport Cooperation Project (SEACOP), Project CRIMJUST, Support Programme to the Maritime Security Strategy (PASSMAR), Support to West Africa Integrated Maritime Security (SWAIMS).

${ }^{41}$ Shared Vision, Common Action: A Stronger Europe - A Global Strategy for the European Union's Foreign And Security Policy. 06. 2016. https://eeas.europa.eu/archives/docs/top_stories/pdf/eugs_review_web.pdf(Letöltés időpontja: 2020. 03. 10.)

42 Aleksander Cyprian Kozera: Black Holes of Insecurity - The North of Mali. In: Besenyő János - Marsai Viktor (eds.): The Dynamics of Conflicts in Africa in the Early $21^{\text {st }}$ Century. Dialóg Campus, Budapest, $2018,43-61$. https://www.researchgate.net/profile/Janos_Besenyo/publication/329626002_The_Dynamics_of_Conflicts in_Africa_in_the_Early_21st_Century/links/5c1279ee4585157ac1c05575/The-Dynamics-of-Conflicts-inAfrica-in-the-Early-21st-Century.pdf (Letöltés időpontja: 2020. 08. 04.) 
az instabilitást és a csempészetet kihasználó szélsőséges fegyveres csoportokra is súlyos csapást lehetne mérni. Szomália esetében a nemzetközi erőfeszítések - például a flottaegységek és légimozgékony reagáló erők járőrözése, a szárazföldi kalózbázisok rombolása a környezö államok érdekeltségének megteremtésével és bevonásával, illetve a hajózási cégek és a magán biztonsági cégek egymásra találása - eredményesnek bizonyultak a kalózkodás jelenségének felszámolásában. Ez a recept jó eséllyel alkalmazható lenne a Guineai-öbölben is: ehhez azonban szükséges lenne az érdekek egybeesésére a számtalan érdekelt fél között, ami viszont még messze nincs meg, elodázva ezzel a probléma megoldását.

\section{FELHASZNÁLT IRODALOM}

2050 Africa's Integrated Maritime Strategy 2050 (AIMS 2050). African Union, 2012. https://cggrps. com/wp-content/uploads/2050-AIM-Strategy_EN.pdf

Africa Maritime Law Enforcement Partnership (AMLEP) Program. United States Africa Comand. https://www.africom.mil/what-we-do/security-cooperation/africa-maritime-law-enforcementpartnership-amlep-program

Andritsos, Fivos: Port Security \& Access Control - A systemic approach. Conference Paper, 07. 2013. https://www.researchgate.net/profile/Fivos_Andritsos/publication/249009738_Port_Security_Access_ Control_a_Systemic_Approach/links/00b7d51e287817956d000000/Port-Security-Access-Controla-Systemic-Approach.pdf

Bálint Tamás - Zsitkó Mariann: A Niger-delta Felszabaditási Mozgalom (MEND). In: Kiss Álmos Péter (szerk.): Afrikai terrorista és szakadár szervezetek. HVK Tudományos Kutatóhely - NKE, Budapest, 2016, 319-339.

Code of Conduct Concerning the Repression of Piracy, Armed Robbery against Ships and Illicit Maritime Activity in West and Central Africa. 25. 06. 2013. http://www.imo.org/en/OurWork/ Security/WestAfrica/Documents/code_of_conduct $\% 20$ signed $\% 20$ from $\% 20$ ECOWAS $\% 20$ site.pdf

Dirk, Steffen: A Niger Delta militant group declares war on the Nigerian Navy. Center for International Maritime Security, 30. 04. 2016. http://cimsec.org/niger-delta-militant-group-declares-war-nigeriannavy/24958

Dirk, Steffen: West African navies coming of age? Center for International Maritime Security, 07. 032016. http://cimsec.org/coming-of-age-of-the-west-african-navies/22919

EU Maritime Security Factsheet: The Gulf of Guinea. EU External Action, 29. 10. 2018. https://eeas.europa. eu/headquarters/headquarters-homepage/52490/eu-maritime-security-factsheet-gulf-guinea_en

European Union Maritime Security Strategy. Council of the European Union, 24. 06. 2014. http://register. consilium.europa.eu/doc/srv?1=EN\&f=ST\%2011205\%202014\%20INIT

Four Dead, Three Kidnapped in Nigerian Pirate Attack. The Maritime Executive, 05. 01. 2020. https:// www.maritime-executive.com/article/four-dead-three-kidnapped-in-nigerian-pirate-attack

Goodman, Amy: Analysis: Somalia Piracy Began in Response to Illegal Fishing and Toxic Dumping by Western Ships off Somali Coast. Democracy Now, 14. 04. 2009. https://www.democracynow.org/ 2009/4/14/analysis_somalia_piracy_began_in_response

Greenberg, Michael D. - Chalk, Peter - Willis, Henry H. - Khilko, Ivan - Ortiz, David S.: Maritime Terrorism - Risk and Liability. RAND Corporation, 2006. https://www.rand.org/content/dam/ rand/pubs/monographs/2006/RAND_MG520.pdf

Implementing sustainable maritime security measures in West and Central Africa. IMO, 01. 2014. http:// www.imo.org/en/OurWork/Security/WestAfrica/Documents/IMO\%20WCA\%20strategy\%20 January\%202014.pdf 
Konotey-Ahulu, Olivia: Pirates Now Prefer Human Hostages Over Ships And Cargo. Bloomberg, 20. 12. 2019. https://www.bloomberg.com/news/articles/2019-12-20/pirates-now-prefer-human-hostagesover-ships-and-cargo

Kozera, Aleksander Cyprian: Black Holes of Insecurity - The North of Mali. In: Besenyő János - Marsai Viktor (eds.): The Dynamics of Conflicts in Africa in the Early $21{ }^{\text {st }}$ Century. Dialóg Campus, Budapest, 2018, 43-61.https://www.researchgate.net/profile/Janos_Besenyo/publication/329626002_The Dynamics_of_Conflicts_in_Africa_in_the_Early_21st_Century/links/5c1279ee4585157ac1c05575/ The-Dynamics-of-Conflicts-in-Africa-in-the-Early-21st-Century.pdf

Lengyel Tamás (szerk.): Közlekedésföldrajz. http://geografus.elte.hu/web/tananyag/3/ipar/gy/kozlfoldrajz. pdf

Memorandum of Understanding on the Establishment of a Sub-Regional Integrated Coast Guard Function Network. https://iea.uoregon.edu/treaty-text/2008-mousubregionalcoastguardnetworkwest centralafricaentxt

Østensen, Åse Gilje - Brady, Sheelagh - Schütte, Sofie Arjon: Capacity building for the Nigerian Navy: Eyes wide shut on corruption? U4 Issue 2018:4. Anti-corruption Resource Centre. https://www. u4.no/publications/capacity-building-for-the-nigerian-navy-eyes-wide-shut-on-corruption.pdf

Piracy and Armed Robbery against Ships, Annual Report, 01. January - 31. December 2006. ICCIMB. https://www.icc-ccs.org/reports/2006_Annual_IMB_Piracy_Report.pdf

Piracy and Armed Robbery against Ships, Annual Report, 01. January - 31. December 2018. ICC-IMB. https://www.icc-ccs.org/reports/2018_Annual_IMB_Piracy_Report.pdf

Piracy and Armed Robbery against Ships, Annual Report, 01. January - 31. December 2019. ICCIMB. icc-ccs.org/reports/2019

Piracy and Armed Robbery Against Ships, Report for the Period. 01. January - 31. December 2019. ICC-IMB. https://www.icc-ccs.org/reports/2019_Annual_Piracy_Report.pdf

Review of Maritime Transport 2018. United Nations Conference on Trade and Development. https:// unctad.org/en/PublicationsLibrary/rmt2018_en.pdf

Rodrigue, Jean-Paul: Maritime Routes and Strategic Passages. In: Jean-Paul Rodrigue: The Geography of Transport Systems. Routledge, New York, 2020. https://transportgeography.org/wp-content/ uploads/Map_Strategic_Passages.pdf

Shared Vision, Common Action: A Stronger Europe - A Global Strategy for the European Union's Foreign And Security Policy. 06. 2016. https://eeas.europa.eu/archives/docs/top_stories/pdf/eugs_review_web.pdf

Starr, Stephen: Maritime Piracy on the Rise in West Africa. Combating Terrorism Center Sentinel, 04. 2014. https://ctc.usma.edu/maritime-piracy-on-the-rise-in-west-africa

Varga Attila Ferenc: Nemzetközi küzdelem a szomáliai kalózkodás ellen. http://mhtt.eu/hadtudomany/ 2011/2011_elektronikus/2011_e_14.pdf 